\title{
Regional Inequality in Medium Term Credit Flow by the DCCBs in Maharashtra, India
}

\author{
S.D. Raut*, S.S. Wadkar, J.M. Talathi, J.S. Dhekale and V.A. Thorat \\ Department of Agricultural Economics, College of Agriculture, Dr. BSKKV., \\ Dapoli, Dist- Ratnagiri, India \\ *Corresponding author
}

\section{A B S T R A C T}

\begin{tabular}{|l|}
\hline Ke y w o r d s \\
Regional inequality, \\
Coefficient of \\
Variance, Theils \\
Entropy Coefficient, \\
Gini ratio and Lorenz \\
curve
\end{tabular}

The present study entitled "Performance of District Central Cooperative Banks in Maharashtra State" has been undertaken to examine the performance of DCCBs in Maharashtra by way of studying the trends in performance indicators both period wise and region wise. The attempt has been made to examine purpose wise lending activities by DCCBs and share of DCCBs in total credit disbursement for agriculture in Maharashtra. The attempt has been made to examine the magnitude and direction of inequality in the flow of credit and the determinants in the short term credit amongst the regions in the state. The problems faced by the DCCBs in disbursing and recovery of agricultural loans have been studied along with the remedial measures. The study is based on secondary data obtained from 30 DCCBs in Maharashtra for the period of past 15 years from 2000-012014-15. The credit gap based upon the scale of finance exercised in different regions and the actual requirement for different crop was studied. The region wise Coefficient of Variance (CV), Theils Entropy Coefficient I (Yi), Gini ratio and Lorenz curve were used for measuring regional inequality in the disbursement of short term and medium term credit in the state. The results showed that there was an inequality in per hectare short term credit flow in all the regions and state as whole during study period.

\section{Introduction}

A co-operative bank is a financial entity which belongs to its members, the owners and the customers of their bank. Agriculture sector plays a strategic role in the process of economic development. As the World Bank describes, "Credit is often a key element in the modernization of agriculture". In India, agriculture loans are mostly provided by cooperative banks, commercial banks, regional rural banks etc. among these co-operative banks play an important role in the rural credit. The District central co-operative banks are the most important institutional agency.

The cooperatives occupy a place of pride in the economy of Maharashtra. Besides they providing credit to agriculture and allied activities. The DCCBs in played a pivotal role in the socio economic development of the rural masses. The DCCBs have been facing actual problems of overdue owing to unsatisfactory performance in its recovery. 


\section{Materials and Methods}

The 36 district central co-operative banks in Maharashtra were selected for the study. Out of 36 DCCBs, 30 DCCBs were more than 15 years old and 6 DCCBs (newly created) were less than 15 years old. Hence in all the 30 District Central Co-operative banks in Maharashtra were selected for the study. However, the sample varied according to the response obtained for a particular aspect of the study. For instance, the officials of 22 DCCBs in the state responded to the aspect relating to the problems of DCCBs.

As regards the study of inequality in distribution of credit (short and medium), the data obtained from 29 (excluding Mumbai District Central Co-operative Bank) DCCBs were utilized. For other aspects of study particularly the work performance, all the 30 DCCBs formed the sample of study.

The regional inequalities in the short term loans by DCCBs were assessed with the help of following measures of inequality. The region wise Coefficient of Variance (CV), Theils Entropy Coefficient I $\left(\mathrm{Y}_{\mathrm{i}}\right)$, Gini ratio and Lorenz curve were used for measuring regional inequality in the disbursement of short term and medium term credit in the state.

\section{Coefficient of variation}

To accomplish the objective relating to the inequality, the region wise coefficient of variation $(\mathrm{CV})$ was calculated for each of the 15 years (2000-01 to 2014-15) by using the following formula. (Jadhav, 2004 and Bhosale, 2011)

$\mathrm{CV}=\frac{\mathrm{SD}}{\text { Mean }} \times 100$

Where,
$\mathrm{CV}=$ Coefficient of variation

$\mathrm{SD}=$ Standard deviation

Mean $=\sum X / N$

$\mathrm{X}=$ per hectare credit flow

$\mathrm{N}=$ Number of districts

Taking CV as dependent variable and time as independent variable to examine the region wise inequality over the period of 15 years

\section{Theils entropy}

Theil (1967) evolved the measure of inequality to assess the income inequality which was given by (Jadhav, 2004 and Sale, 2014)

$H\left(Y_{i}\right)=\sum_{i=1}^{N} Y_{i} \quad X \quad \log \quad\left(\frac{1}{Y_{i}}\right)$

Where,

$\mathrm{H}\left(\mathrm{Y}_{\mathrm{i}}\right)=$ Theils entropy

$Y_{i}=$ Proportion of $i^{\text {th }}$ district in the total credit flow from DCCBs in the State

$\mathrm{H}\left(\mathrm{Y}_{\mathrm{i}}\right)$ has been modified and is given by

$\mathrm{I}\left(\mathrm{Y}_{\mathrm{i}}\right)=\log \mathrm{N}-\mathrm{H}\left(\mathrm{Y}_{\mathrm{i}}\right)$

Where,

I $(\mathrm{Yi})=$ Theils entropy coefficient which ranges from 0 to $\log \mathrm{N}$

$\mathrm{N}=$ Number of districts

Taking I (Yi) as dependent variable, linear trend equation was fitted to examine the regionwise inequality over the period of 15 years (2000-01 to 2014-15).

$\mathrm{I}\left(\mathrm{Y}_{\mathrm{i}}\right)=\mathrm{a}+\mathrm{bt}+\mathrm{u}$ 
The regression coefficient was tested for its statistical significance. A significant positive regression coefficient indicates an increase in the variability in credit flow while a significantly negative regression coefficient indicates a tendency of reduction in variability over the last 15 years period (2000-01 to 2014-15).

\section{Gini ratio}

The Gini ratio (L) is estimated as follows. (Grewal, 1987)

$L=1-\frac{\sum_{i=1}^{N}\left(P_{i}-P_{i-1}\right) \quad X \quad\left(Q_{i}-Q_{i-1}\right)}{10000}$

Where,

$\mathrm{P}_{\mathrm{i}}=$ Cumulative percentage of number of DCCBs up to and including $i^{\text {th }}$ class.

$\mathrm{Q}_{\mathrm{i}}=$ Cumulative percentage of credit flow per hectare of gross cropped area by DCCBs up to and including $\mathrm{i}^{\text {th }}$ class

$\mathrm{N}=$ Number of DCCBs.

Higher the value of Gini ratio (L), more is the inequality in distribution of credit and vice versa $(0<\mathrm{L}<1)$.

\section{Lorenz curve technique}

A measure of income inequality developed by Kuznets (1963) by constructing Lorenz curve has also been used here. It is the graphical representation of cumulative proportion of number of DCCBs in Maharashtra on horizontal $\mathrm{X}$-axis and cumulative proportion of agricultural credit flow per hectare of gross cropped area by DCCBs on the vertical Yaxis. The line of equal distribution is the straight line at $45^{\circ}$ angle joining $(0,0)$ and
$(100,100)$ points. The degree to which a line Lorenz Curve deviates from the line of equal distribution is a measure of the inequality of disbursement of loan. Further, the curve moves away from the equality line, the greater is the inequality (Grewal, 1987). Both Gini Ratios and Lorenz Curves were obtained for base year, mid-year and terminal year of the study.

\section{Results and Discussion}

The inter-regional inequality in credit flow by DCCBs over the years was assessed by using different measures. The findings are briefly explained in the discussion that follows.

\section{Coefficient of variance for medium term credit flow}

In order to examine whether or not the DCCBs disbursed the medium term credit uniformly across the regions and state, the coefficient of variation was computed for each year from the period 2000-01 to 2014-15. The trend equations were fitted by taking coefficient of Variance as dependent variables and time as independent variable for each of the regions and at the State level, separately. The region wise coefficients of Variance in medium term credit flow by DCCBs during 2000-01 to 2014-15 are presented in Table 1.

It could be seen from the Table 1 that the coefficient of variation of medium term credit flow per hectare of GCA across the regions was low at 108.65 per cent in 2001-02 and the highest at 197.11 per cent in 2003-04 at the state level. The Coefficient of Variance in medium term credit flow in case of Western Maharashtra it was low 83.25 per cent in year 2001-02 and highest 128.58 per cent in the year 2009-10. The Coefficient of Variance in medium term credit flow in case of Konkan region it was low 64.20 per cent in year 20014-15 and highest 177.86 per cent in the 
year 2008-09. The coefficient of variance in medium term credit flow in case of Marathwada region it was low 111.95 per cent in year 2001-02 and highest 251.81 per cent in the year 2006-07. The Coefficient of Variance in medium term credit flow in case of Vidarbha region it was low 73.94 per cent in year 2004-5 and highest 156.02 per cent in the year 2006-07. The average variation across the years in the state was 146.62 per cent. The average variation across the years was highest in Marathwada region (162.50 per cent) followed by Konkan (113.88 per cent), Vidarbha (107.28 per cent) and lowest in Western Maharashtra (100.88 per cent) respectively.

The regression coefficients for medium term credit flow, the trend equations were positive and non-significant in all regions and at the state level, which indicated non-significantly increases in variation in the medium term credit flow over the study period. At the state level, Coefficient of Variance for medium term credit flow across the years indicated that there was a moderate inequality in the disbursement of medium term credit flow by the DCCBs

\section{Theils entropy index for medium term credit flow}

In order to examine whether or not the DCCBs disbursed the medium term credit flow uniformly across the regions and state, the Theils Entropy was employed. The trend equations were fitted by taking Entropy coefficient I (Yi) as dependent variables and time as independent variable for each of the regions and at the state level, separately. The region wise Theils Entropy coefficient for medium term credit flow by DCCBs during 2000-01 to 2014-15 are presented in Table 2. Table 2, revealed that the Theils entropy coefficient was as low as 1.35 in 2014-15 and as high as 1.42 in years from 2007-08 to 2008- 09at the state level. The average value of the coefficient (inequality across the years) for Maharashtra state was 1.39.The Theils entropy coefficient in medium term credit flow in case of Western Maharashtra it was low 0.85 in year 2004-05, 2011-12 and 2014-15and highest 0.91 in the year 2008-09. The Theils entropy coefficient in medium term credit flow in case of Konkan region it was low 0.44 in year 2009-10 and highest 0.58 in the year 2005-06. Theils entropy coefficient in medium term credit flow in case of Marathwada region it was low 0.70 in year 2004-05 and highest 0.83 in the year 2012-13 to 2014-15.

The Theils entropy coefficient in medium term credit flow in case of Vidarbha region it was low 0.81 in year 2014-15 and highest 0.92 in the year 2001-02 and 2002-03. The average variation across the years in the state was 1.39. The average variation across the years was highest in Vidarbha region (0.88) and Western Maharashtra (0.88) followed by Marathwada (0.79) and lowest in Konkan (0.54) respectively. The regression coefficients for medium term credit flow, the trend equations were negative and non-significant in Western Maharashtra and at the state level, which indicate non-significantly declining in inequality in the medium term credit flow over the period. The regression coefficients for medium term credit flow, the trend equations were negative and significant in Konkan and Vidarbha region which indicate significant declining in inequality in the medium term credit flow over the study period. The regression coefficient in Marathwada region for medium term credit flow was showed positive and significant trend which indicate significantly increases in inequality in the disbursement of medium term credit flow. At the state level, Theils entropy coefficient for medium term credit flow across the years indicated that there was a moderate inequality in the disbursement of medium term credit flow by the DCCBs. 
Fig.1 Lorenz curve for medium term credit flow in different regions of Maharashtra

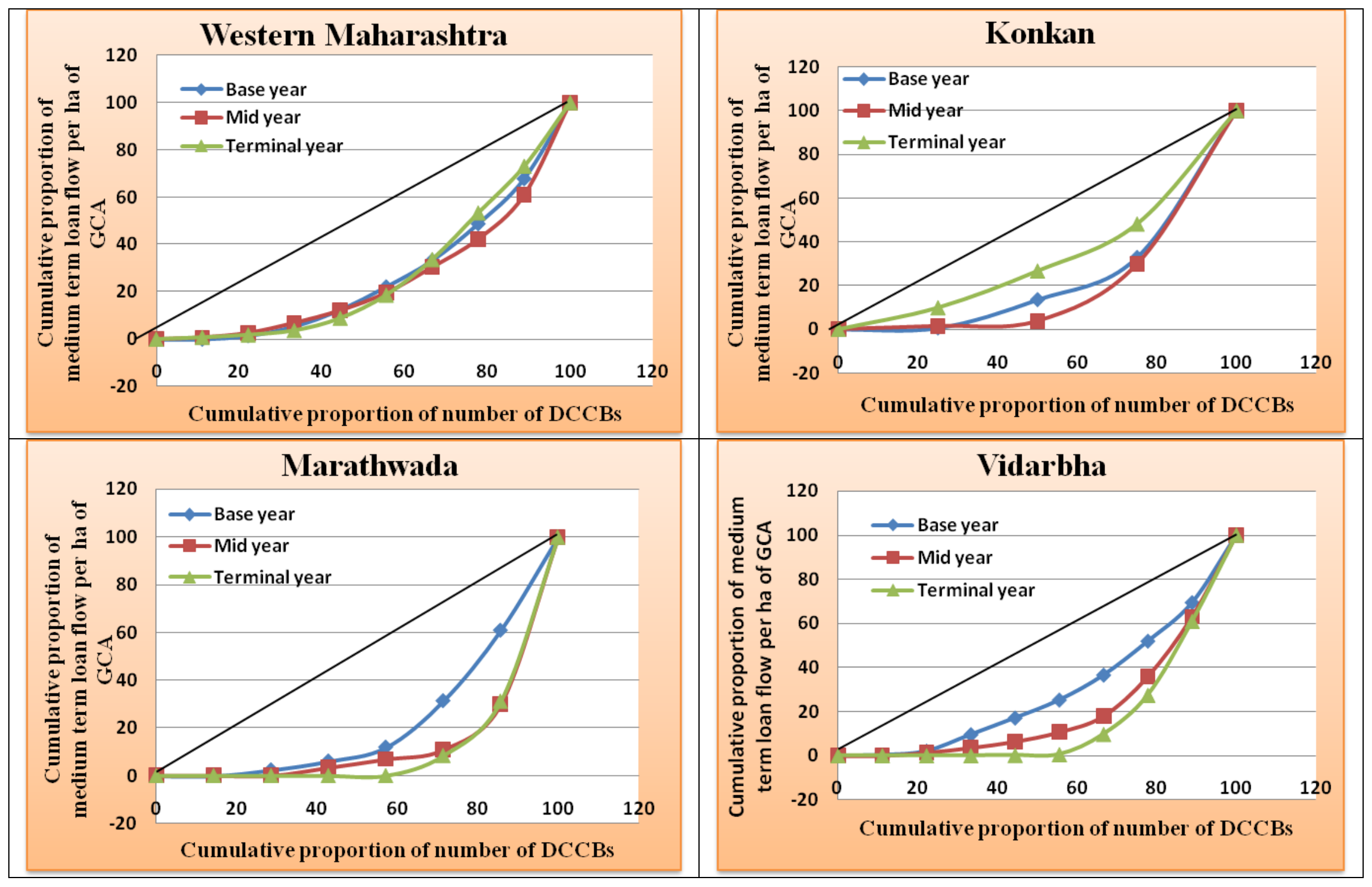


Fig.2 Lorenz curve for medium term credit flow in Maharashtra

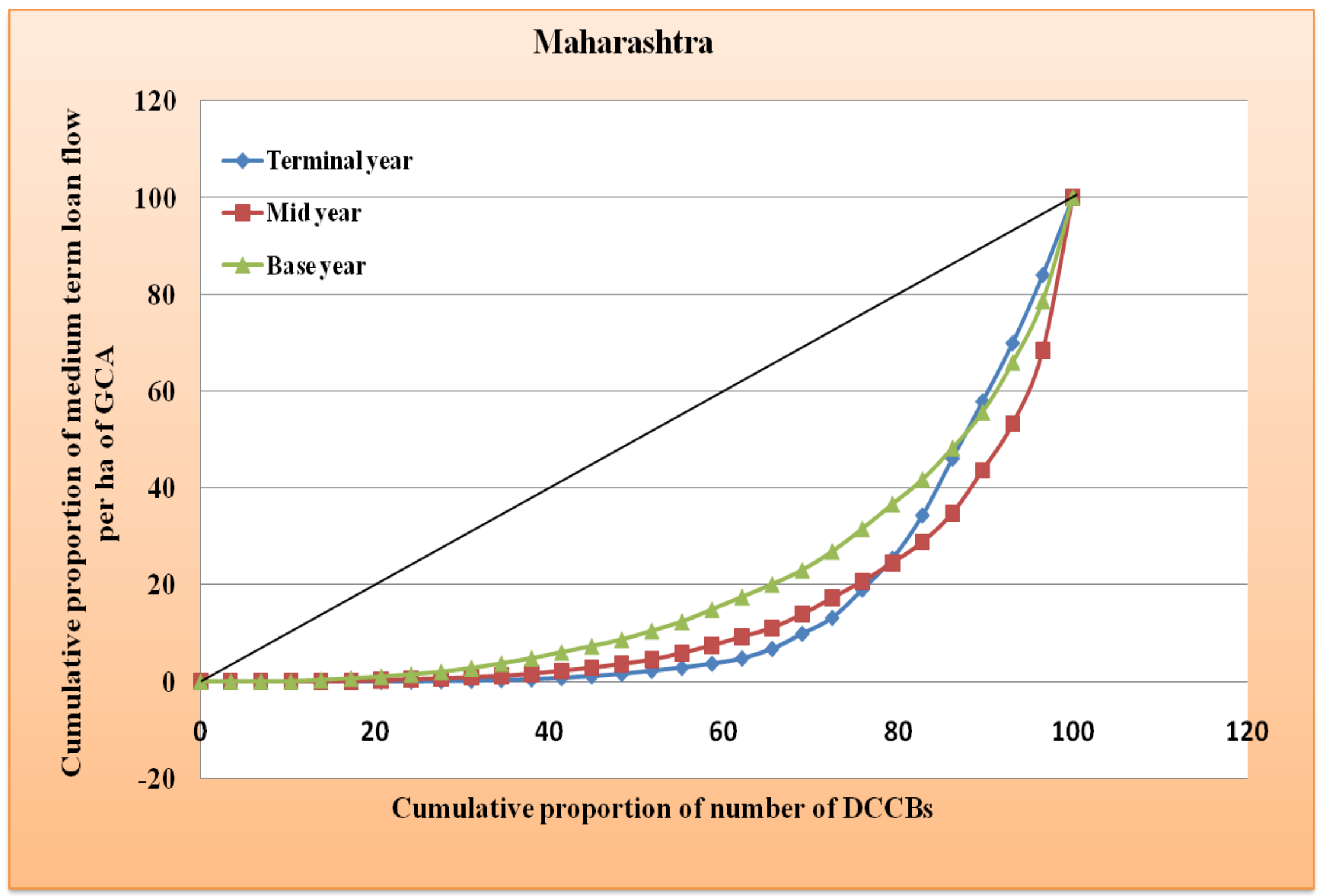


Table.1 Region wise coefficient of variance in medium term credit flow by DCCBs during 200001 to 2014-15 in Maharashtra

(CV in percent)

\begin{tabular}{|c|c|c|c|c|c|}
\hline Years & Konkan & $\begin{array}{c}\text { Western } \\
\text { Maharashtra }\end{array}$ & Marathwada & Vidarbha & Maharashtra \\
\hline 2000-01 & 105.40 & 84.50 & 112.39 & 88.22 & 110.14 \\
\hline 2001-02 & 106.61 & 83.25 & 111.95 & 88.54 & 108.65 \\
\hline 2002-03 & 90.67 & 111.35 & 165.40 & 86.97 & 165.68 \\
\hline 2003-04 & 95.92 & 123.70 & 168.95 & 125.11 & 197.11 \\
\hline 2004-05 & 105.59 & 90.43 & 131.13 & 73.94 & 118.40 \\
\hline 2005-06 & 94.84 & 89.74 & 161.57 & 128.00 & 124.08 \\
\hline 2006-07 & 128.76 & 89.07 & 251.81 & 156.02 & 143.63 \\
\hline 2007-08 & 115.32 & 92.01 & 188.88 & 105.55 & 146.01 \\
\hline 2008-09 & 177.86 & 116.82 & 146.73 & 82.25 & 179.85 \\
\hline $2009-10$ & 122.93 & 128.58 & 170.88 & 105.00 & 154.14 \\
\hline 2010-11 & 135.65 & 95.75 & 137.30 & 131.16 & 140.79 \\
\hline 2011-12 & 127.33 & 97.88 & 152.64 & 115.94 & 147.66 \\
\hline 2012-13 & 123.43 & 102.79 & 170.85 & 83.58 & 152.56 \\
\hline 2013-14 & 113.74 & 120.19 & 173.93 & 98.13 & 178.74 \\
\hline 2014-15 & 64.20 & 87.12 & 193.10 & 140.79 & 131.87 \\
\hline Average & 113.88 & 100.88 & 162.50 & 107.28 & 146.62 \\
\hline $\begin{array}{c}\text { No. of } \\
\text { Districts }\end{array}$ & 4 & 9 & 7 & 9 & 29 \\
\hline
\end{tabular}

\begin{tabular}{l|l} 
Konkan & $\mathrm{CV}=107.05+0.85^{\mathrm{NS}}$ \\
Western Maharashtra & $\mathrm{CV}=94.73+0.76^{\mathrm{NS}}(1.55)$ \\
Marathwada & $\mathrm{CV}=138.76+2.96^{\mathrm{NS}}$ \\
Vidarbha & $\mathrm{CV}=95.16+1.51^{\mathrm{NS}}(1.99)$ \\
Maharashtra & $\mathrm{CV}=133.11+1.68^{\mathrm{NS}}$
\end{tabular}

(Figures in parentheses are the standard errors of respective coefficients)

* Significant at 5 per cent level, NS=Non-Significant 
Table. 2 Trends in regional in equality in medium term credit flow by DCCBs during 2000-01 to 2014-15 in Maharashtra

Theils Entropy Coefficient, I ( $\left.\mathrm{Y}_{\mathrm{i}}\right)$

\begin{tabular}{|c|c|c|c|c|c|}
\hline Year & Konkan & $\begin{array}{c}\text { Western } \\
\text { Maharashtra }\end{array}$ & Marathwada & Vidarbha & Maharashtra \\
\hline $\mathbf{2 0 0 0 - 0 1}$ & 0.57 & 0.90 & 0.77 & 0.90 & 1.41 \\
\hline $\mathbf{2 0 0 1 - 0 2}$ & 0.56 & 0.90 & 0.76 & 0.90 & 1.40 \\
\hline $\mathbf{2 0 0 2 - 0 3}$ & 0.55 & 0.89 & 0.77 & 0.92 & 1.40 \\
\hline $\mathbf{2 0 0 3 - 0 4}$ & 0.56 & 0.87 & 0.80 & 0.92 & 1.39 \\
\hline $\mathbf{2 0 0 4 - 0 5}$ & 0.56 & 0.85 & 0.70 & 0.85 & 1.34 \\
\hline $\mathbf{2 0 0 5 - 0 6}$ & 0.58 & 0.88 & 0.73 & 0.88 & 1.39 \\
\hline $\mathbf{2 0 0 6 - 0 7}$ & 0.56 & 0.88 & 0.81 & 0.88 & 1.39 \\
\hline $\mathbf{2 0 0 7 - 0 8}$ & 0.57 & 0.90 & 0.81 & 0.92 & 1.42 \\
\hline $\mathbf{2 0 0 8 - 0 9}$ & 0.52 & 0.91 & 0.81 & 0.91 & 1.42 \\
\hline $\mathbf{2 0 0 9 - 1 0}$ & 0.44 & 0.88 & 0.82 & 0.88 & 1.39 \\
\hline $\mathbf{2 0 1 0 - 1 1}$ & 0.53 & 0.86 & 0.79 & 0.84 & 1.36 \\
\hline $\mathbf{2 0 1 1 - 1 2}$ & 0.52 & 0.85 & 0.81 & 0.85 & 1.37 \\
\hline $\mathbf{2 0 1 2 - 1 3}$ & 0.50 & 0.88 & 0.83 & 0.89 & 1.39 \\
\hline $\mathbf{2 0 1 3 - 1 4}$ & 0.50 & 0.88 & 0.83 & 0.91 & 1.39 \\
\hline $\mathbf{2 0 1 4 - 1 5}$ & 0.51 & 0.85 & 0.83 & 0.81 & 1.35 \\
\hline A verage & $\mathbf{0 . 5 4}$ & $\mathbf{0 . 8 8}$ & $\mathbf{0 . 7 9}$ & $\mathbf{0 . 8 8}$ & $\mathbf{1 . 3 9}$ \\
\hline Log N value & $\mathbf{0 . 6 0}$ & $\mathbf{0 . 9 5}$ & $\mathbf{0 . 8 5}$ & $\mathbf{0 . 9 5}$ & $\mathbf{1 . 4 6}$ \\
\hline
\end{tabular}

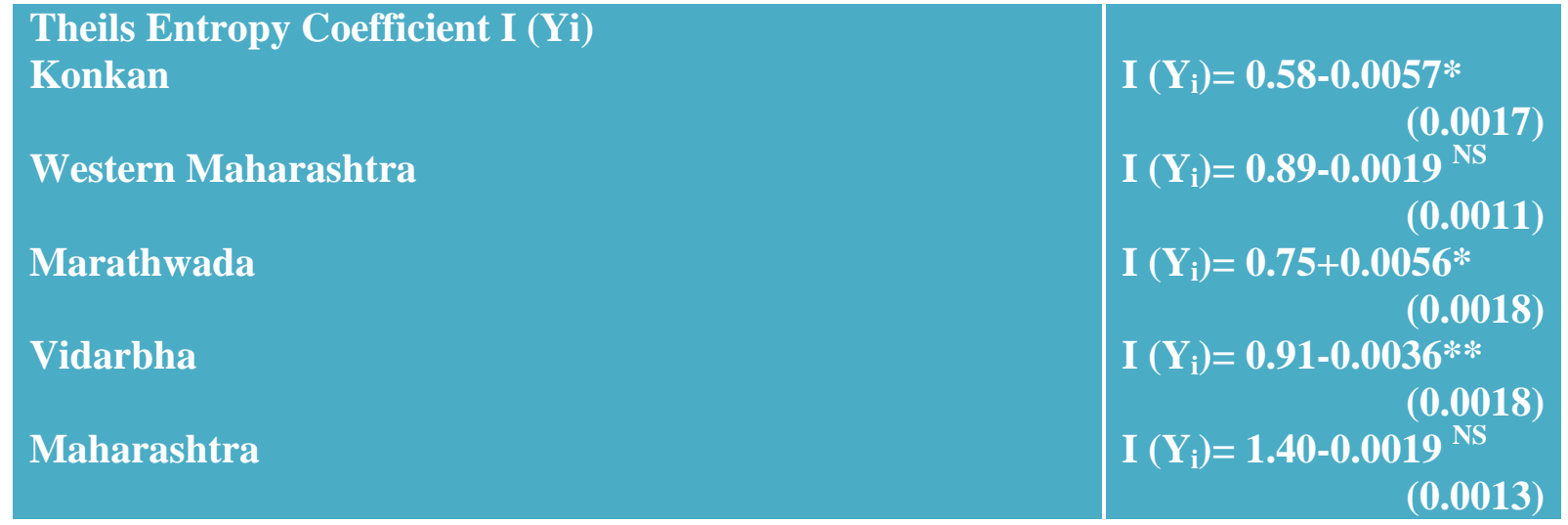

(Figures in parentheses are the standard errors of respective coefficients)

$*$ and $* *$ Significant at 5 and 10 per cent level, NS=Non-Significant

Table.3 Gini coefficient of regional inequality in medium term agricultural credit flow by DCCBs in Maharashtra

\begin{tabular}{|l|c|c|c|c|c|}
\multicolumn{1}{|c|}{ Year } & Konkan & $\begin{array}{c}\text { Western } \\
\text { Maharashtra }\end{array}$ & $\begin{array}{c}\text { Marathwa } \\
\text { da }\end{array}$ & $\begin{array}{c}\text { Vidarbh } \\
\text { a }\end{array}$ & $\begin{array}{c}\text { Maharashtr } \\
\text { a }\end{array}$ \\
\hline Base year (2000-01) & 0.51 & 0.46 & 0.53 & 0.42 & 0.61 \\
\hline Mid-year (2007-08) & 0.58 & 0.5 & 0.71 & 0.58 & 0.72 \\
\hline Terminal year (2014-15) & 0.33 & 0.46 & 0.74 & 0.67 & 0.72 \\
\hline
\end{tabular}


Gini concentration ratio and Lorenz curve analysis for medium term credit flow

From the Table 3, it was observed that the Gini ratio was $0.61,0.72$ and 0.72 for the base year, mid-year and terminal year, respectively for medium term credit flow, indicating moderate intra-regional inequality in medium term credit flow by DCCBs in Maharashtra.

The results of Gini ratio and Lorenz curve for medium term credit flow showed an increase in intra-regional inequality in the mid-year and constant in terminal year of the study.

Lorenz curve was constructed for medium term agricultural credit for all the regions and state as a whole separately. This presents a picture of the cumulative percentage of DCCBs for the individual regions or Maharashtra state on the ' $\mathrm{X}$ ' axis and cumulative percentage of agricultural credit given by DCCBs per hectare of gross cropped area on the ' $\mathrm{Y}$ ' axis for the base year, midyear and terminal year.

Figure 1 and 2 present the Lorenz curves for medium term agricultural credit was concerning to base year, mid-year and terminal year depicting inter-regional and intra-regional inequality. It could be seen that these curves being was away from the line of equal distribution $\left(45^{0}\right.$ degree line $)$ indicated unequal distribution of short-term agricultural credit among the regions and among the districts in the regions during study period in Maharashtra state.

As regards the inter-regional inequality in the medium term credit flow, the results of the Gini ratio and Lorenz curve showed increase in inequality in Marathwada and Vidarbha region over the years, while in Western Maharashtra and Konkan region it was increased in the mid-year and subsequent reduction in inequality in the terminal year of the study. As regards the intra-regional inequality in the medium term credit flow in the state level it was observed that the Gini ratio was 0.61 in the base year, which had increased to 0.72 in the average year and constant 0.72 in the terminal year of the study. This has indicated that inequality at the state level showed in increase in the average year and constant in the terminal year of the study.

For measuring inequality the various inequality measures like Coefficient of variance, Theils entropy coefficient and Gini ratios were used for per hectare short term and medium term credit flow. From the results it was observed that there is inequality in medium credit flow in all regions and state as a whole.

The coefficient of variance, Theils entropy coefficient, Gini ratio and Lorenz curve were used for measuring inequality in disbursement of medium term credit flow by DCCBs in Maharashtra state. The results showed that there was an inequality in per hectare short term credit flow in all the regions and state as whole during study period. For reduce inequality the some measures, like opening new branches, proper credit plan and monitoring with due weightage to productivity of credit.

\section{References}

Bhosale, S.S. 2012. Performance of District Central Co-operative Banks in Konkan Region of Maharashtra. Agricultural Economics Research Review, 25(1): 177.

Grewal, P.S 1987. Numerical Methods of Statistical Analysis, published by Sterling Publisher Pvt. Ltd., New Delhi.

Jadhav, A.J 2009. Performance analysis of Pune DCCB in Maharashtra. Unpublished thesis submitted to 
Mahatma Phule Krishi Vidyapeeth, Rahuri, Maharashtra.

Jadhav, K. L 2004. Performance analysis of district central co-operative banks in Maharashtra. Unpublished thesis submitted to Mahatma Phule Krishi Vidyapeeth, Rahuri, Maharashtra.

Jairath, M.S 1990. Regional disparities in cooperative credit services in Himachal Pradesh. Indian Co-operative Review, 27(3): 240-249.

Ramesha, K. 1990. A study on growth and extent of disparities in PACS between districts: A case of Kerala. Indian Cooperative Review, 27(3): 334-344.

Sale, Y. C. 2014. Economic analysis of acquisition, utilization and repayment of institutional and non-institutional loan for agriculture in Maharashtra. Unpublished thesis submitted to MPKV, Rahuri.

Satyasai, K. J. S 2012. Access to rural credit and input use: An empirical study. Agricultural Economics Research Review, 25: 461-471.

\section{How to cite this article:}

Raut, S.D., S.S. Wadkar, J.M. Talathi, J.S. Dhekale and Thorat, V.A. 2018. Regional Inequality in Medium Term Credit Flow by the DCCBs in Maharashtra, India. Int.J.Curr.Microbiol.App.Sci. 7(01): 2589-2598. doi: https://doi.org/10.20546/ijcmas.2018.701.311 